\title{
Effect of cotyledons and epicotyl upon the activity of endogenous gibberellins in roots of flax (Linum usitatissimum L.) seedlings
}

\author{
KR YSTYNA M. JANAS 1 and JIRI SEBANEK 2 \\ 1 Laboratory of Plant Growth Substances, University of Lodz, \\ Banacha 12/16, 90-237 Eódź, Poland \\ 2 Department of Botany and Plant Physiology, University of Agriculture, \\ Zemědělska 1, 662-65 Brno, Czechoslovakia \\ (Received: February 12, 1980)
}

Abstract

In 11-day-old flax seedlings, the level of endogenous gibberellins in roots decreased within 12 hours after the excision of cotyledons and the epicotyl; however, 24 to 48 hours after excision the gibberellin level increased again. The decrease in the gibberellin level within the first 12 hours after excision suggests a participation of the cotyledons and the epicotyl in the biosynthesis of endogenous gibberellins.

Control of growth of cultivated in practical plants by the use of growth regulators requires, the knowledge how these regulators affect endogenously particular growth correlations within the plant. Plant seedlings are especially suitable objects for such studies. Flax represents very good model plant with epigeic cotyledons. S e bá n e k et al. (1979) studied the principle of promoting effects of the root in flax seedlings. They found that excision of roots resulted in a decrease in the level of endogenous gibberellins in cotyledons. In this paper we try to explain the problem of participation of cotyledons and the first epicotylar leaves in the gibberellic activity in roots.

For experiments flax (Linum usitatissimum L. cv. 'Vĕra') plants were grown in vegetation pots containing garden earth under continuous illumination of 3000 lux at the $21-24^{\circ} \mathrm{C}$. At the age of 11 days the seedlings were divided into 5 groups. The content of endogenous gibberellins (GA) was estimated in roots in all groups. The first group consisted of intact plants. In the other groups the cotyledons and epicotyls were removed $6,12,24$ and $48 \mathrm{~h}$ before GA estimation. There were 2 epicotylar leaves on the seedlings on the 11 th day of their 
growth. Endogenous GA was estimated in homogenized samples ( $2 \mathrm{~g}$ ) of seedlings roots. The samples were extracted with methyl alcohol and subjected to thin-layer chromatography on silicagel $G$ in the mixture of chlorophorm, ethylacetate and acetic acid (60:40:5), (S e mbdner et al., 1962). Extract of chromatogram sections with individual Rf volues were tested on lettuce seedlings of cv. 'Král máje' (Frankland and W a reing, 1961). For a detailed description of the method see Ko p e c ḱ̀ et al. (1975).

As compared with intact plants, a decrease of the endogenous GA content took place in the roots within the first 12 hours after excision of cotyledons and the epicotyl. However, 24 hours after excision the content of GA in roots returned approximately to the level in intact plants. Fourty eight hours after excision, the level of GA in roots was even higher than that in intact plants. Similar results were obtained in three replications of this experiment.

Experimental results showed that cotyledons and the two first epicotylar leaves undoubtedly participated in the gibberellic activity of flax seedling roots. Using the same experimental object it was demonstrated, however, that the root also participated significantly in this activity because its excision resulted in a decrease in the level of endogenous GA in the cotyledons (S e b á n e $\mathrm{k}$ et al., 1979). Participation
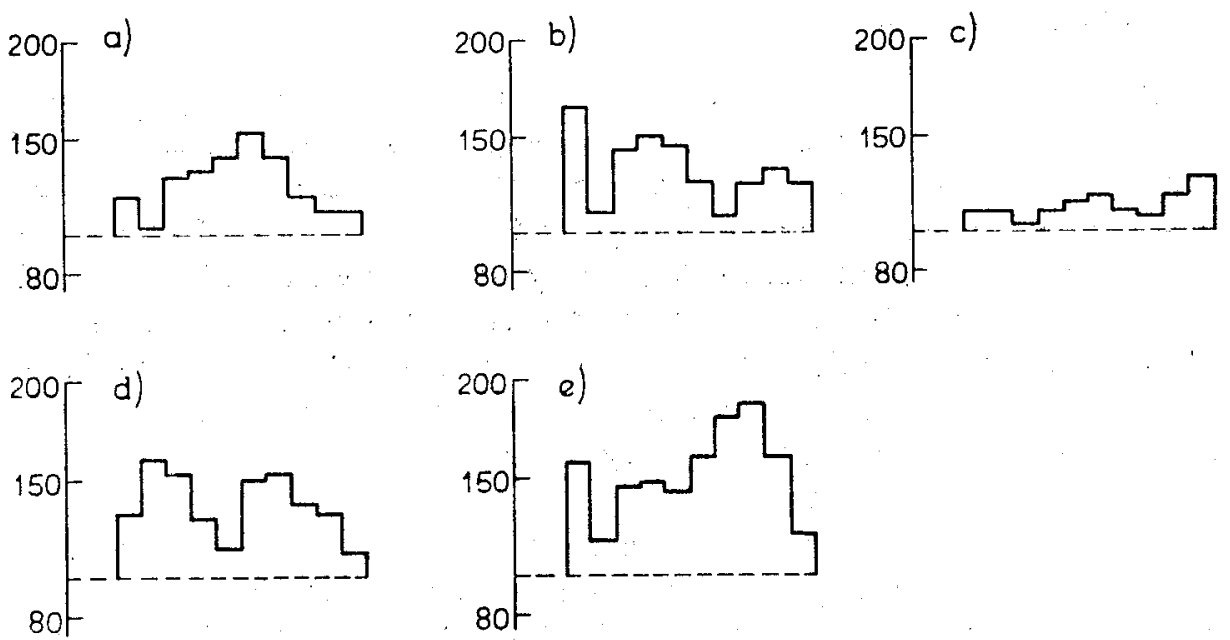

Fig. 1. Chromatographic estimation of endogenous gibberellins in roots of flax seedlings

$a-$ intact plants; $b-e-$ plants deprived of cotyledons and the epicotyl for: $b-6 h$; $\mathrm{c}-12 \mathrm{~h} ; \mathrm{d}-24 \mathrm{~h} ; \mathrm{e}-48 \mathrm{~h}$;

Elongation of hypocotyls of lettuce seedlings $(\%)$ against controls $(100 \%)$ is presented on the $y$ axis, $R f$ values on the $x$ axis 
of roots in the biosynthesis of GA was indicated also by experimental results obtained with other plant species (C a r r et al., 1964). It is also probable that the ability of roots to biosynthetize endogenous GA participated in, or contributed to the increase in the level of endogenous gibberellins found within 24 and especially 48 hours after excision of the cotyledons and epicotyl. The decrease of GA-activity in the roots during the 6-12 hour period after cotyledons and epicotyl excision may be also the result of exhaustion of the factor stimulating GA synthesis in roots which is normally produced in the aerial parts of the plant. Regeneration of its synthesis in the remaining aerial part may contribute to the renewal of GA synthesis in the roots (Š e bá n e k, 1966).

\section{REFERENCES}

Carr D. J., Read D. M. and Skene K. G. M., 1964. The supply of gibberellins from the root to the shoot. Planta 63: 382-392.

Frankland B., Wareing P. F., 1961. Effect of gibberellic acid on hypocotyl growth of lettuce seedlings. Nature 185: 255-256.

Kopecký F., Ś̉bánek J., Blažková J., 1975. Time course of changes in the level of endogenous growth regulators during the stratification of the seeds of Panenské české apple. Biol. Plant 17: 81-87.

S e bán ek J., 1966. Einfluss des Kinetins auf den Gehalt endogener Gibberelline in den Wurzeln dekapitierter Erbsenkeimlinge. Naturwissenschaften 53: 336.

Sebánek J., Tan H. M., Klíčová S., 1979. Role of endogenous auxins and gibberellins in growth-correlative effects of root metabolism and in the hypocotyl regeneration of flax seedlings. Biol. Physiol. Pflanzen 174: 691-695. Sembdner G., Gross R., Schreiber K., 1962. Die Dünnschichtchromatographie von Gibberellinen. Experientia 18: 584-585.

Wpływ liścieni i epikotylu na aktywność endogennych giberelin w korzeniach Inu (Linum usitatissimum L.)

Streszczenie

Po 12 godz. od momentu usunięcia liścieni i epikotylu u 11-dniowych roślin lnu, dochodzi do obniżenia poziomu endogennych giberelin $w$ korzeniach. Po 24-48 godz. od tej amputacji następuje podwyższenie aktywności giberelin w korzeniach inu. Obniżenie aktywności giberelin do 12 godz. od amputacji liścieni i epikotylu świadczy o możliwości uczestniczenia epikotylu i liścieni w biosyntezie endogennych giberelin. 